\title{
Evaluation of Some Serum Biochemical Parameters of Humans Exposed to Burnt Tire Emissions
}

\section{CHUKU, LC; *ONYEGEME-OKERENTA, BM; OBIA, C}

\author{
Department of Biochemistry, Faculty of Science, University of Port Harcourt, Rivers State, Nigeria. \\ *Corresponding Author: Email: blessing.onyegeme-okerenta@uniport.edu.ng \\ Tel: +234(0)8035201039
}

\begin{abstract}
Evaluation of some serum biochemical parameters of humans who were exposed to burnt tire emissions (singeing process) was carried out in this study. Eighty (80) healthy adult males were recruited for the study after their consents were sought. Fifty-five (55) of them served as the experimental subjects while twenty-five (25) of them served as the control subjects. The experimental subjects were some singers at Trans Amadi (Oginigba), Port Harcourt abattoir. The control subjects were some Port Harcourt residents that are not occupationally exposed to singeing. Venous blood samples were collected from both the experimental and control groups; and their sera were screened to determine the levels of C-reactive protein (CRP), prostate-specific antigen (PSA), carcinoembryonic antigen (CEA), alpha-fetoprotein (AFP), total serum protein (TSP) and total globulins (TG). The results of the screening showed that the serum levels of prostate-specific antigen and carcinoembryonic antigen of both the experimental and the control subjects were within normal range. However, the serum C-reactive protein and alpha-fetoprotein of many experimental subjects were above the normal range. Also, the majority of the experimental and control subjects had total globulins below the normal range and total serum protein that were within the normal range. The mean and standard deviation of the screened parameters for the experimental subjects were 1.17 $\pm 0.80,1.52 \pm 0.54,2.42 \pm 1.19$, $13.20 \pm 6.86,67.27 \pm 14.11$ and $2.10 \pm 1.22$ for C-reactive protein, prostate-specific antigen, carcinoembryonic antigen, alpha-fetoprotein, total serum protein and total globulins respectively. For the control subjects, the mean and standard deviation of the screened parameters were $0.26 \pm 0.22,1.10 \pm 0.37,2.81 \pm 3.14,6.51 \pm 3.50,70.34 \pm 4.43$ and $22.97 \pm 5.06$ for C-reactive protein, prostate-specific antigen, carcinoembryonic antigen, alpha-fetoprotein, total serum protein and total globulins respectively. In conclusion, the study has demonstrated that alpha-fetoprotein and C-reactive protein are elevated in the serum of the experimental subjects who are occupationally exposed to singeing process.
\end{abstract}

\section{DOI: https://dx.doi.org/10.4314/jasem.v22i10.21}

Copyright: Copyright $\left({ }^{\circ} 2018\right.$ Chuku et al. This is an open access article distributed under the Creative Commons Attribution License (CCL), which permits unrestricted use, distribution, and reproduction in any medium, provided the original work is properly cited.

Dates: Received: 18 August 2018; Revised: 27 September 2018; Accepted: 30 October 2018

Keywords: Singeing, abattoir, Prostate-specific antigen, C-reactive protein, Carcinoembryonic antigen

The burning of solid fuels (wood, animal dung, coal, etc) usually involves elevated temperature and altered pressures; and genotoxicant e.g. polycyclic aromatic hydrocarbons (PAHs) are likely to form (Claxton, 2014). These substances cause cancer in test animals. Studies have shown that PAHs that are present in solid fuel emissions react with $\mathrm{NO}_{2}$ to form direct-acting mutagen and many of the measured genotoxicants found in and out of the room combustors are the same. Therefore, the severities of health effect vary with exposure and with the state of health of the exposed population (Marilena et al., 2007). Open fires of burning scrap tires create thick black harmful smoke and release stupendous poisonous solid and gaseous hazardous emissions if not controlled (Anf and Emad, 2014). The smoke and toxic material released from the burning of tires may wreak havoc on the environment, cause nuisance and threaten wellness and safeness of folks. The scrapings of roasted slaughtered animals have very high heavy metals concentration above maximum permissible level and incidentally are potential seedbeds of heavy metal in surface water, soil and plant. Roasting of slaughtered goats with tires increases the heavy metal concentrations in the hide, or skin of the slaughtered animal which diffuse into the body beyond the acceptable limit (Friday and Nwite, 2016). The tire as a product is environmentally friendly; however, the additives and their product of combustion and degradation are brought into the environs where they create staggering health and ecological problems. Particulate matters have been linked with a lot of health challenges primarily involving the cardiopulmonary system. However, particles of divergent components may play a critical role in these effects (Ya-mei et al.,2003). In Port Harcourt metropolis, Rivers State and perhaps other parts of Nigeria, tires are used as fuel to burn the fur of cattle, goats, dogs and etc. This process emits black smoke into the atmosphere. The roasters directly inhale this hazardous smoke, and the neighbourhood

*Corresponding Author: Email: blessing.onyegeme-okerenta@uniport.edu.ng

Tel: +234 (0)8035201039 
residents also inhale the sooty smoke as it diffuses. This study was aimed at evaluating some serum biochemical parameters of humans who were exposed to burnt tire emissions.

\section{MATERIALS AND METHODS}

Experimental design: The eighty (80) healthy male subjects recruited for this study were divided into two major groups: the experimental or trial group which comprised of fifty-five (55) individuals; and the control group which comprised of twenty-five (25) individuals. Ethical approval with number UPH/CEREMAD/REC/04 was obtained from the Ethical Committee of the School of Post Graduate Studies, University of Port Harcourt. The experimental subjects were singers at an abattoir located in Trans Amadi (Oginigba), Port Harcourt, Rivers State, Nigeria. These subjects singe animals with tire and directly inhale the smoke.

Sample collection: The blood samples were collected via venepuncture from the subjects after their consents were sought. Their respective age and the duration of exposure of the experimental subjects were documented. The samples collected were spun in a centrifuge within 24 hours of collection. The spinning separated the serum from the formed elements. The sera obtained were stored at $-4^{\mathrm{O}} \mathrm{C}$.

Method of laboratory analysis: Prostate-specific antigen, Carcinoembryonic antigen, and Alpha fetoprotein were measured using enzyme-linked immunosorbent assay (ELISA), C-reactive protein was measured using turbimetric immunoassay, and total serum proteins were measured using biuret method.

Data analysis: Descriptive statistics (Mean and standard deviation) and inferential statistics (t-test and ANOVA) were used to analyse the data, with $\mathrm{p}<0.05$ regarded as statistically significant.

\section{RESULTS AND DISCUSSION}

Figure 1 shows the mean of CRP for the trial subjects that have been exposed to the singeing process for a duration of 1 - 15 yrs. It was observed that CRP for each group was significantly higher $(\mathrm{p}<0.05)$ than the reference standard. It further showed a trend of the duration of contact-dependent response to tire fire emission; the longer the duration of exposure, the higher the concentration of C-reactive protein present in the serum of experimental subjects. CRP of experimrntal subjects with respect to their age is shown in Figure 2. Values obtained showed a significant in the experimental groups when compared to the normal reference level. The group with subjects who are between forty to forty-nine years had the highest mean, while the group which comprised of subjects who are between the ages of thirty to thirtynine years had the lowest mean value of CRP. High level of CRP in these subjects portends chronic inflammatory reactions, high risk of cardiovascular disease, and high risk of lung and colon cancers. The concentration of $\mathrm{C}$-reactive protein present in the serum of experimental subjects is proportional to the duration of exposure of subjects to singeing process. There is a connection between the towering amount of C-Reactive protein and risk of developing cancer (Allin et al., 2011). A study conducted by Ani et al., 2010 linked increase level of C-reactive protein to a high risk of lungs cancer; suggesting an etiologic role for chronic pulmonary inflammation in lung carcinogenesis. Emissions from open tire fires have been shown to be more mutagenic than those of a combustor, irrespective of the fuel (Reisman, 1997). Mutagens are carcinogens, and exposure to mutagen brings about cancer formation. Eighteen (18) carcinogens, including aflatoxins B1, benzo(a)pyrene, acetylaminofluorene, benzidine, etc. are known to be activated by liver homogenates to form potent frameshift mutation (Bruce et al., 1973); and cellular protooncogenes can be activated by both point mutations and chromosomal translocation, suggesting that there may be a direct link between exposure to agents which damage DNA and genetic change leading to malignancy ( Miguel and Ken, 1986). On the other hand, older subjects, and subjects exposed for a prolonged period of time were more affected than the younger ones, and those exposed for a short period of time. This is not unconnected with the fact that aging results in changes in hepatic structure and function. Physiologic changes take place during the aging process; these changes can influence biotransformation reactions in the liver (Birnbaum 1991). A decrease in liver size and blood flow to the liver together with a reduction in metabolic ability, have been demonstrated in elderly (Anantharaju et al. 2002). The aged body has a reduced capacity to remove foreign chemicals from the body (Zeeh and Platt 2002). It has been observed that the body's capacity to act on medications is compromised in people that are advanced in age (Aramaki et al. 1998; Hazzard et al. 1999). From the age of 30, some of our physiologic systems start to decline; and as we become old, our homeostatic reserves shrink, negatively affecting the body's capacity to respond to environmental change or toxins (NRC 1987). The observation in this study that older subjects were more affected than younger ones with respect to alphafetoprotein levels is in accordance with the finding of Kinirons and O'Mahony (2004). Kinirons and 
O'Mahony in 2004 reviewed the literature regarding changes in drug metabolism with age. They found that age-related decrease in the function of some but not all, cytochrome P450 enzymes (CYPs) had been identified, but that there is a significant variation among individuals in drug metabolism with advancing age.

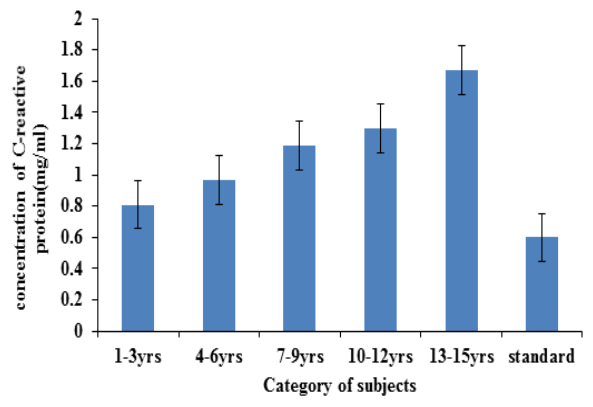

Fig 1: Mean C-reactive protein of the experimental subjects according to duration of exposure

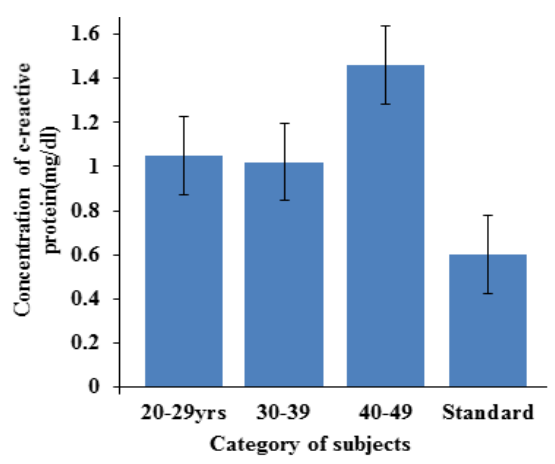

Fig 2: Mean C-reactive protein of the experimental subjects according to their age

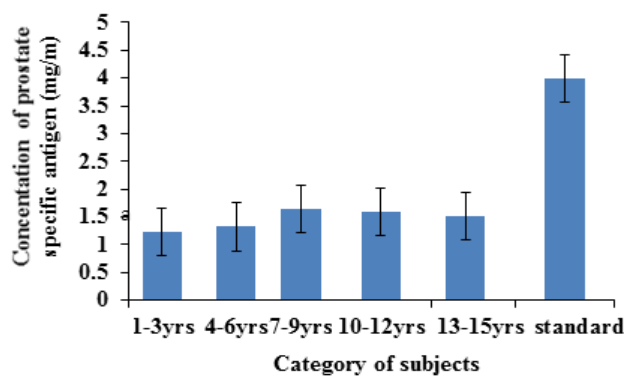

Fig 3: Mean PSA of the experimental subjects according to duration of exposure

PSA values obtained (Figure 3) for individuals that have been occupationally exposed to singeing process (tire fire emissions) for 1-15yrs showed a significant decrease $(\mathrm{p}<0.05)$ for each group when compared with the standard reference value. However, the duration of exposure did not affect the level of PSA of all the groups.

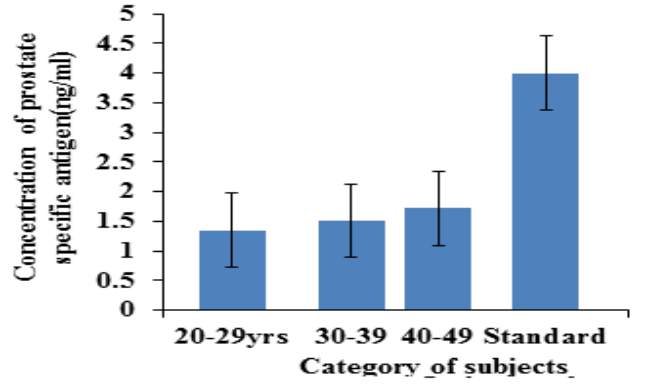

Fig 4: Mean PSA of the experimental subjects according to their age

Similarly, PSA level of subjects from various categories with respect to age (Figure 4) was significantly lower $(\mathrm{p}<0.05)$ when compared with the standard reference value. The group with subjects who are between forty to forty-nine years had the highest mean PSA value while the group which comprises of subjects who are between the ages of twenty to twentynine years had the lowest mean PSA value. The results of the study have also shown that the serum levels of PSA of both the experimental and the control subjects were not beyond the normal levels. Normal levels of PSA in both the experimental and the control individuals suggests that these subjects generally have healthy prostate gland; and that the singeing process which the trial individuals are vocationally exposed to did not affect their prostate glands or perhaps, have not started taking its toll on their prostate glands. PSA is present in small amount in the serum of men with healthy prostate but is elevated in the presence of prostate cancer or other prostate disorders (Cartolona et al., 1994). According to Sukkarieh, 2014, prostate cancer in young men is more aggressive, and therefore more life-threatening than in older men. Men that are young do not normally go for prostate screening and rectal exams until the age of about 50 years old, and this common cancer in men usually does not show any physical symptoms when it is in its early stage. The study has therefore shown that there is no link between exposure to tire fire emissions and inflammatory and neoplastic diseases of the prostate gland in middleaged men. However, the difference between the PSA of the experimental and the control groups was not statistically significant $(\mathrm{p}>0.05)$.

Presence of carcinoembryonic antigen was assayed for in the trial subjects that have been occupationally exposed to tire fire emissions for between 1 and $15 \mathrm{yrs}$ (Figure 5).

Values obtained when compared with the standard reference value showed a significant decrease $(\mathrm{p}<0.05)$ in mean CEA for each group. 


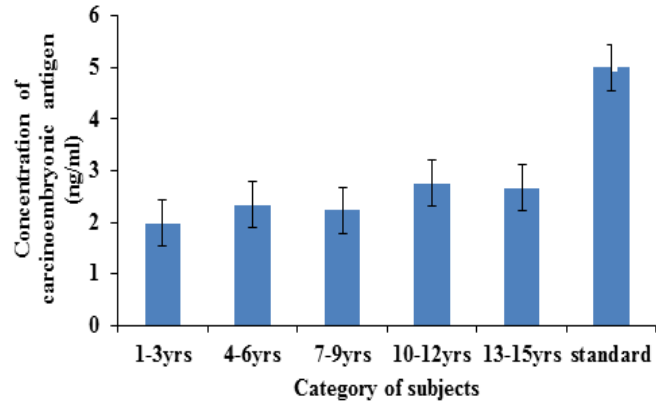

Fig 5: Mean CEA of the experimental subjects according to duration of exposure

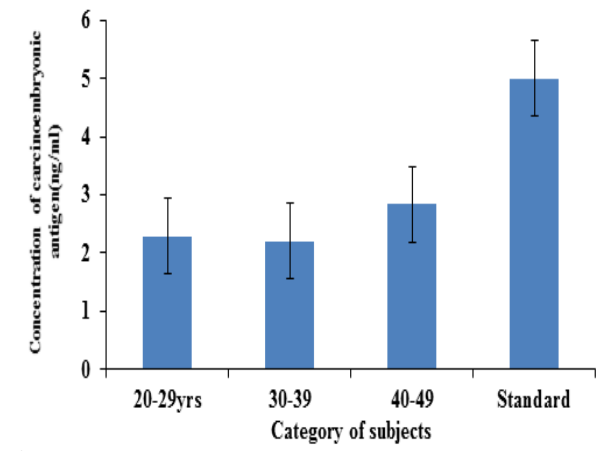

Fig 6: Mean carcinoembryonic antigen of the experimental subjects according to their age

However, the duration of exposure did not lead to an increase in CEA levels. Results obtained in Figure 6 similarly showed a significant decrease $(\mathrm{p}<0.05)$ in CEA levels to be in conformity with their age groups. However, the figures did not show that age affects their response to tire fire emission. According to Hashem et $a l$, 2007; CEA and vascular endothelial growth factors (VEGF) are some of the most important prognostic markers of colorectal cancer, the second most prevalent cancer and a leading cause of death. CEA is expressed in number of normal tissues such as the colon, stomach, tongue, oesophagus, cervix, sweat glands and the prostate.

In colorectal cancer, however, its concentration is elevated and the general distribution of the molecule on the cell surface is also altered. CEA is considered one of the most clinically relevant tumour markers for colorectal cancer; providing information on prognosis, tumour recurrence and metastasis (Duffy, 2004). Therefore, the normal levels of CEA in these subjects depict that they are free of CEA-associated neoplastic diseases. The difference between the experimental and the control subjects in terms of their carcinoembryonic antigen was statistically significant $(\mathrm{p}<0.05)$. Similarly, the difference that exists among the various groups of the experimental subjects, both in terms of exposure duration and age were statistically significant $(\mathrm{p}<0.05)$. Figure 7 shows the mean alpha-fetoprotein for the trial individuals that have been occupationally exposed to singeing process of $1-15 \mathrm{yrs}$. The result indicates a significant increase $(\mathrm{p}<0.05)$ in mean AFP for each group when compared with the standard reference value. It also showed that the group with the longer duration of exposure had the highest mean whereas the group with the shortest time of exposure had the lowest mean; the longer the length of exposure, the higher the concentration of AFP.

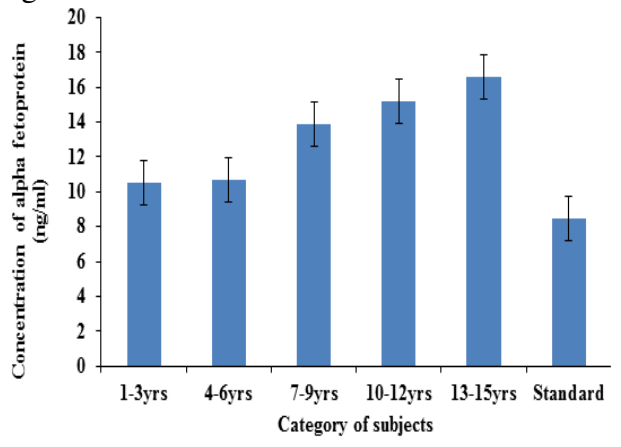

Fig 7: Mean alpha fetoprotein of the experimental subjects

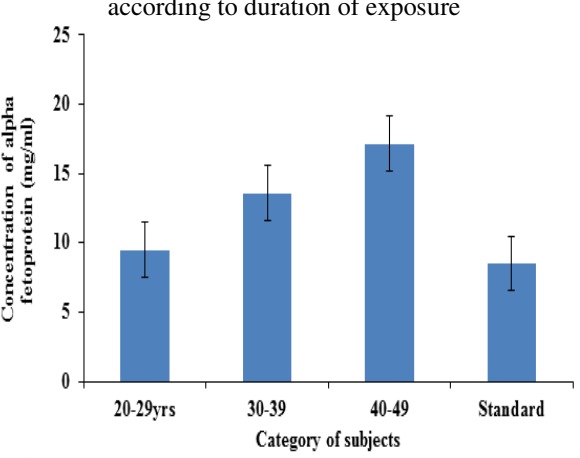

Fig 8: Mean alpha fetoprotein of the experimental subjects according to their age

Mean AFP concentration of experimental subjects with respect to their age (Figure 8) showed a significant increase $(p<0.05)$ when compared with the standard reference value. The group with subjects who are between forty to forty-nine years had the highest mean value of AFP while the group which comprises of subjects who are between the ages of twenty to twenty-nine years had the lowest mean. Singeing process in an abattoir involves superficially burning off loose fur on the skin of the animal and abattoir workers are occupationally exposed to this process every day of their work life. The results of this study have demonstrated that the AFP and C-reactive protein levels of the experimental subjects were above the normal limit with the mean and standard deviation $=13.20 \pm 6.86$ and $1.17 \pm 0.80$ respectively. High level of AFP in these subjects is an index of hepatocellular carcinoma (HCC). According to Philip et al, 2001, 
AFP levels fall rapidly instantly after birth to become virtually undetectable. It rises again only when certain pathological conditions develop. It has been observed for nearly 40 years that re-expression of AFF is consistently occursing in subjects with hepatocellular carcinoma. Also, high level of serum AFP in these subjects could be a pointer of germ cell carcinoma. According to the publication of American society of clinical oncology by Gilligan et al. (2010), during the screening of germ cell tumours, a sample of blood may be collected to test for levels of serum tumour markers. High levels of any one of the three tumour markers called alpha-fetoprotein (AFP), human chorionic gonadotropin (HCG), and lactate dehydrogenase $(\mathrm{LDH})$ may indicate a germ cell tumour. With respect to AFP, the results showed a statistically significant difference between the experimental and the control subject $(\mathrm{p}<0.05)$.

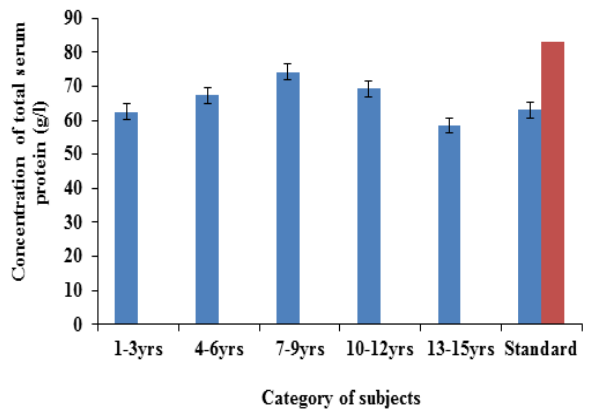

Fig 9: Mean total serum protein (TSP) of the experimental subjects

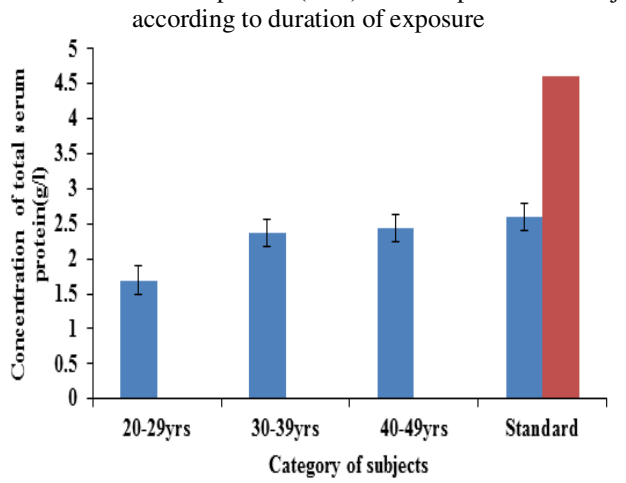

Fig 10: Mean total serum protein (TSP) of experimental subjects according to their age

Results obtained in Figure 9 and Figure 10 showed non-significant $(p>0.05)$ differences in the Total Serum Protein in terms of age and duration of the trial individuals that have been occupationally exposed to singeing process when compared with the standard reference value. The results of the study also showed that the total serum protein of the experimental and the control subjects were within the normal range. Serum protein is one of the common bio-molecules that are regularly evaluated as screening tests for unearthing diseases or for following up the activity of a disease; alterations of their levels, although not specific may be of diagnostic significance in people with complex diseases (Putignano, et al., 2000). In all, subjects that are between the ages of 20-29yrs had lower serum total protein than the ones between the age of 30-39yrs and 40-49yrs. This is in disagreement with the report of Tian et al, 2014. Tian and others investigated the distribution of serum total protein in elderly Chinese. According to them, the serum total protein levels possibly decrease with aging.

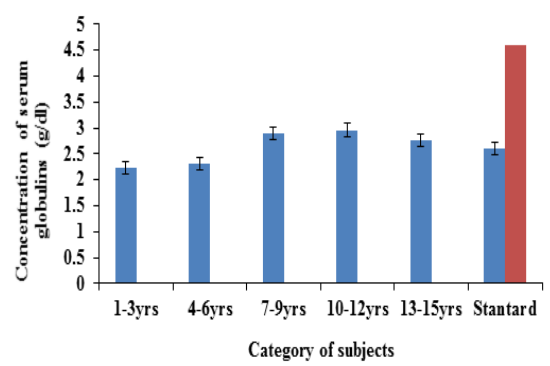

Fig 11: Mean total globulins of the experimental subjects according to duration of exposure

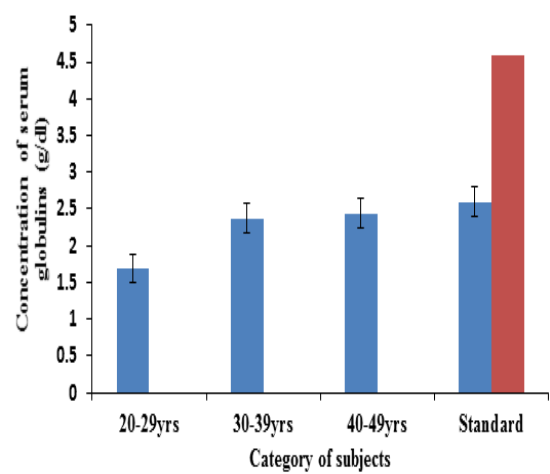

Fig 12: Mean total globulins of the experimental subjects according to their age

The average serum globulins for the trial subjects that have been exposed to singeing process for 1 to $15 \mathrm{yrs}$ (Figures 11) showed that serum globulins for the group which comprised of subjects exposed for 7-9yrs was within the normal range while the average serum globulins of other groups were significantly $(\mathrm{p}<0.05)$ below the standard reference value. The group with the longer duration of exposure had the lowest mean globulin level. Similarly, the mean of serum globulins for the trial subjects based on age (Figure 12) showed the means of the three groups were significantly $(\mathrm{p}<0.05)$ below the standard reference value. The group with subjects who are more advanced in age had a higher mean than the group with subjects who are less advanced in age. The serum globulins many experimental subjects and their control counterparts 
were found to be below the normal range. Significant depressions of gamma globulins are usually found in the serum of patients with protein-losing enteropathy, exfoliative dermatitis nephrotic syndrome or severe malnutrition. Defective synthesis of gamma globulins often times follows cancer of the lymphoid system, especially reticulum-cell sarcoma, lymphosarcoma, Hodgkin's disease and chronic lymphocytic leukemia (Fred et al, 1966). According to Walker et.al, (1990); malnutrition and congenital immune deficiency can lead to a fall in total globulins due to a reduction in its synthesis. When the mean of serum globulins for the experimental and the control subjects were compared, the difference between them was not statistically significant $(p>0.05)$. However, when the means of serum globulins for the various groups of the experimental subjects with regards to the length of exposure were compared, the differences that exist among them was statistically significant $(\mathrm{p}<0.05)$.

Conclusion: Most of the experimental subjects have serum C-reactive protein and alpha-fetoprotein levels that are above the normal range. This could be attributed to their been occupationally exposed to singeing process. Duration of exposure and age of the subjects affected the levels of these biomarkers in their sera. This is evident in older subjects and subjects exposed for a longer period. Therefore, it can be concluded that these subjects have either developed neoplastic diseases of the liver, lungs, colon, germ cells, etc. or they are on the verge of developing them.

Acknowledgment: The authors acknowledge the support of the volunteers from the abattoir located at Trans Amadi (Oginigba), Port Harcourt, Rivers State, Nigeria.

\section{REFERENCES}

Allin, KH; Nordestgaard, BG; Zacho, J; TybjaergHansen, A; Bojesen, SE (2010). C-reactive protein and the risk of cancer: a mendelian randomization study. JouJ. Nat. Cancer Inst. 102, 202-6.

Allin, KH; Nordestgaard, BG; Zacho, J; TybjaergHansen, A; Bojesen, SE (2010). C-reactive protein and the risk of cancer: a mendelian randomization study. J. Nat.Cancer Inst. 102, 202-6.

Allin, KH; Noredestgaard, BG (2011). Elevated CRP in diagnosis: a review in clinical laboratory sciences, 4th edition, 155-170.

Anantharaju, AFA; Chedid, A (2002). Aging liver: a review. Gerontology, 48(6), 343-353.
Anf, HZ; Emad, S (2014). An environmental impact assessment of the open burning of scrap tires. $J$. Appl. Sci. 14(1): 2695-2703.

Aramaki, T; Katsuta, Y; Sekiyama, T; Tsutsui, H; Kome-ichi, H; Ohsuga, M; Satomura, K; Yoshimura, M (1998). Effects of aging and liver disease upon the pharmacokinetics of nipradilol. Cli. Drug Invest. 16(3): 251-257.

Birnbaum, LS (1991). Pharmacokinetic basis of agerelated changes in sensitivity to toxicants. Annu. Rev. Pharmaco. 31, 101-128.

Bruce, NA; Williams, ED; Edith, Y; Frank, DL (1993). Carcinogens are mutagens: a simple test system combining liver homogenates for activation and bacteria for detection. Proc. Natl. Acad. Sci. U.S.A 70(8): 2281-2283.

Catalona, WJ; Richie, JP; Ahmann, FR; Hudson, MA; Scardino, TP; Flanigan, RC; Dekernion, JB; Ratliff, TR; Karouss, IR; Dalkin, BL; Walter, WB; Macfarne, MT; Southwic, PC (1994). Comparison of digital rectal examination and serum prostate specific antigen in the early detection of prostate cancer. J.Am. Urol. Asso. 151(5): 1283-1290.

Claxton, LD (2014). The history of genotoxicity and carcinogenicity of carbon-based fuels and their emissions. Sci. Total Environ. 762(10): 10.

Duffy, MJ (2001). Carcinvembryonic antigen as a marker for colorectal cancer: is it clinical useful? Clin. Chem. 47, 024-630

Fred, S; Rosen, MP; Charles, A (1966). The gamma globulins- the antibody deficiency syndrome. $N$. Engl. J. Med. 275, 769-775.

Friday, AC; Nwite, JN (2016). Implication of roasting goat with tires on human health and the environment in Abakaliki, Ebonyi state Nigeria. $J$. Pollut. Eff. Cont . 10, 4178-4397.

Gilligan, TD; Seidenfeld, J; Basch, EM; Einhorn, LH; Fancher, T; Smith, DC; Stephenson, AJ; Vaughn, DJ; Cosby, R; Hayes, DF (2010). American Society of Clinical Oncology Clinical Practice Guideline on uses of serum tumor markers in adult males with germ cell tumors. J. Clin. Oncol. 28, 3388-3404.

Hashem, AD; Ayman, TD; Fahd, N; Loucine, K; Raghad, A (2007). Significance of CEA and VEGF as diagnostic markers of colorectal cancer 
in Lebanese patients. Open Clinical Cancer Journal, 8(1): 1- 5.

Hazzard, WR; Blass, JP; Ettinger, WH; Halter, JB; Ouslander, JG (1999). Principles of geriatric medicine and gerontology, 4th edn. McGraw-Hill, Health Professions Division, New York, N.Y. 104-116.

Kinirons, MT; O’Mahony, MS (2004). Drug metabolism and aging. Br. J. Clin. Pharmacol. 57(5): 540-544.

Marilena, K; Elias, C (2007). Human health effect of air pollution. Environ. Poll. 151(2): 362-367.

Miguel, Q; Ken, B (1986). Carcinogen-specific mutation and amplification of Ha-ras during mouse skin Carcinogenesis. Nature, 322(1): 7880.

National Research Council (NRC). (1987). Work, aging, and vision. Report of a Conference, National Academy Press, Washington, DC.

Philip, JJ (2001). The role of serum alpha fetoprotein estimation in the diagnosis and management of hepatocellular carcinoma. Clin. Liver Dis. 5(1): 1089-3261.

Putignano, P; Kaltsas, GA; Korbonits, M; Jenkin, PJ; Monson, JP; Besser, GM; Grossman, AB (2000). Alterations in patients with cushing's syndrome before and after successful treatment. J. Clin. Endocrinol. Metab. 85(9): 3309- 3312.
Reisman, J (1997). Air emissions from scrap tire combustion. U.S. Environmental Protection Agency, Washington, D.C., EPA/600/R-97/115, NTIS PB98-111701.

Sukkarieh, T (2014). Prostate cancer in young men: what you should know. CentraState Medical Center in Freehold, N.J. $\mathrm{h}$ ttps://www.livescience.com/48147-fiveprostate-cancer-tips-for-young-men.html

Tian, CR; Qian, L; shen, XZ; Li, JP; Wen, JT (2014). Distribution of serum total protein in elderly Chinese. PLOS one Vol 9 (6) pp 1371.

Walker, HK; Hall, WD; Hurst, JW (1990). Clinical methods: the history, physical and laboratory examinations. 3rd edition, Butterwort, 101.

Ya-mei, Z; Cai-Yung, Z; Kent, EP (2003). Oxidative stress and NFKB activation in the lungs of rats: a synergistic interaction between soot and iron particles. Toxicol. Appl. Pharmacol. 190(2): 157169.

Zeeh, J; Platt, D (2002). The aging liver: structural and functional changes and their consequences for drug treatment in old age. Gerontology, 48(3): 121-127. 